\title{
Stress responses of Indian major carps cultured in the East Kolkata Wetland, West Bengal, India
}

\author{
Anish DAS ${ }^{1}$, Talagunda Srinivasan NAGESH ${ }^{1}$, Sarita DAS', Thangapalam Jawahar ABRAHAM²
}

Cite this article as:

Das, A., Nagesh, T.S., Das, S., Abraham, T.J. (2021). Stres responses of Indian major carps cultured in the East Kolkata Wetland, West, India. Aquatic Research, 4(4), 351-362. https://doi.org/10.3153/AR21030

\footnotetext{
${ }^{1}$ West Bengal University of Animal and Fishery Sciences, Faculty of Fishery Sciences, Department of Fisheries Resource Management, 5, Budherhat Road, Chakgaria, Kolkata - 700 094, India

${ }^{2}$ West Bengal University of Animal and Fishery Sciences, Faculty of Fishery Sciences, Department of Aquatic Animal Health, 5, Budherhat Road, Chakgaria, Kolkata - 700 094, India
}

ORCID IDs of the author(s): A.D. 0000-0003-2693-2418 T.S.N. 0000-0002-6256-5029 S.D. 0000-0003-2820-979X T.J.A. 0000-0003-0581-1307

Submitted: 31.01 .2021

Revision requested: 01.04 .2021

Last revision received: 02.04 .2021

Accepted: 02.04.2021

Published online: 23.06 .2021

\section{Correspondence:}

Thangapalam Jawahar ABRAHAM

E-mail: abrahamti1@gmail.com

\begin{abstract}
Fish are continuously exposed to multiple environmental stressors that work cumulatively and synergistically. This study assessed the stress responses of Indian major carps (IMCs) cultured in a sewage-fed pond (SP) in the East Kolkata Wetland (EKW), India and compared with the normal carps in situ. The experiment was conducted in two farms that cultured Labeo rohita, Catla catla and Cirrhinus mrigala for seven months, covering the summer and winter periods. Serum biomarkers of primary (cortisol) and secondary (glucose, total protein, creatinine, alanine aminotransferase (ALT), aspartate aminotransferase (AST) and lactate dehydrogenase (LDH)) stress responses, and oxidative stress (superoxide dismutase (SOD)) were quantified using standard kits. The health status of carps was evaluated as a tertiary response. The biological oxygen demand, hardness, total dissolved solids, ammonia and phosphate levels of both ponds exhibited marked variations. The SP carps had significantly low haemoglobin and total protein, and high serum glucose, creatinine, ALT, AST and LDH levels. The SOD and cortisol levels were comparatively low in SP carps. The winter temperature had a significant effect on serum glucose, cortisol, SOD, creatinine, ALT and AST. Carps had a high degree of ectoparasitic infestation during the winter. Cirrhinus mrigala of the SP had significantly high serum creatinine levels. The increasing levels of serum glucose, creatinine, ALT and AST suggested that these indices, which were more pronounced in the carps of EKW in conjunction with winter temperature, could be useful biomarkers of stress, kidney and liver functioning in carps, respectively.
\end{abstract}

Keywords: Indian major carps, Fish health, Serum biomarkers, Oxidative stress, Ectoparasites

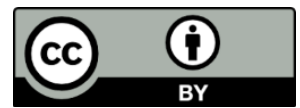

(C) 2021 The Author(s)

Available online at

http://aquatres.scientificwebjournals.com 


\section{Introduction}

Carp culture is the backbone of Indian aquaculture, which has evolved from the level of traditionally backyard activity to viable commercial farming practice. Application of sewage and other wastes in carp culture to augment fish production is in vogue in India since the 1930s (Bhowmik, 2011). Though the Indian major carps (IMCs) are the principal species cultured in the system, other fish groups such as exotic carps, minor carps, tilapia, etc. are also being cultured along with them (Abraham et al., 2010; 2020). Under farm conditions, the inappropriate water quality, inadequate or high stocking density, feed and unscientific management practices that quantitatively or qualitatively not suitable, cause physiological variations. Long-term exposure to these stressors can negatively affect fish growth, health and ultimately productivity (Relić et al., 2010). Among the various stressors, water quality parameters are one of the most influencing ones in fish welfare assessment including fish health, behaviour and productivity (Boyd, 1979; Banerjee et al., 2015). The effects that multiple stressors exhibit on organisms can be synergistic or antagonistic (Petitjean et al., 2019).

The city of Kolkata, India diverts about $60-70 \%$ of its sewage to the East Kolkata Wetlands (EKW). The EKW, a Ramsar site, sustains the world's largest and perhaps oldest integrated resource recovery practice based on a combination of agriculture and aquaculture. It provides livelihood support to a large, economically underprivileged population of around 20,000 families, which depend upon the various wetland products, primarily fish and vegetables for sustenance. The wetlands consist of about 264 sewage-fed fisheries that cover about 12,500 ha (EKWMA, 2010). This massive biological cleaning system is highly productive, and carp aquaculture is quite popular. A considerable amount of fish consumed in Kolkata is produced from this system (SWRE, 2007; Bhowmik, 2011; Banerjee et al., 2015). Fish living in the wastewater-fed ponds are constantly being exposed to varying levels of physicochemical parameters, which may disturb the normal physiological functions of fish leading to stress and infection (Banerjee et al., 2017). The exposure of fish to various biotic and abiotic agents may induce haematological changes. The haematological and biochemical parameters, although highly variable, can provide prognostic information, depending on the fish species, age, the cycle of sexual maturity and health condition (Bernet et al., 2000, 2001, ReyVázquez and Guerrero, 2007). Organ alterations, water quality induced changes in blood chemistry, increased prevalence of infectious diseases, temperature fluctuations and evidence for endocrine disrupting substances were all found to be indicative of an environmentally influenced health condition (Wahli, 2002).
The most comprehensive and effective assessments of fish health are achieved if both (i) short- and long-duration responses, (ii) slow- and fast responding and (iii) contaminantspecific and unspecific biomarkers are conjointly included in environments subjected to complex contaminants, which act synergistically or cumulatively (Sopinka et al., 2016; Petitjean et al., 2019). The alterations in biochemical (glucose, cortisol and protein), enzymological (aspartate aminotransferase (AST), alanine aminotransferase (ALT), lactate dehydrogenase (LDH), superoxide dismutase (SOD)) and other biomarkers are widely used to assess the toxic stress, pollution level, immune status and tissue damage (Kavitha et al., 2010; Chitra-Pakira et al., 2015). There are reports on the carp culture in the sewage-fed ponds (Abraham et al., 2010), accumulation of heavy metals and toxicants in water, sediment and fish (SWRE, 2007; Chatterjee et al., 2010; Sarkar et al., 2011) and increasing incidence of infectious diseases of fish from such systems (Banerjee et al., 2015, 2017). Nevertheless, in situ studies related to serum biomarkers of fish from such an ecosystem are lacking. The present study assessed the primary, secondary and tertiary stress responses of Indian major carps (IMCs) namely Labeo rohita (Hamiton, 1822), Catla catla (Hamilton, 1822) and Cirrhinus mrigala (Hamiton, 1822) cultured in the EKW that received sewage and compared with the normal carps in situ.

\section{Material and Methods}

\section{Site Description and Experimental Design}

The present experiment was carried out in two fish ponds of varied culture conditions. The experiment was conducted in a 2 (farms) $\times 3$ (species) $\times 2$ (seasons) factorial design with two replications in each pond from December to June. The normal pond (NP) of size 0.33 ha was taken from a rain-fed farm situated at the Faculty of Fishery Sciences, Chakgaria, Kolkata (Lat. $22^{\circ} 82^{\prime} \mathrm{N}$; Long. $88^{\circ} 20^{\prime} \mathrm{E}$ ). The sewage-fed pond (SP) of size 18.67 ha was from the EKW situated at Haripota, Bamanghata, South 24 Parganas district, West Bengal, India (Lat. $22^{\circ} 29^{\prime} \mathrm{N}$; Long. $88^{\circ} 29^{\prime} \mathrm{E}$ ). Six nylon netcages $(2.43 \mathrm{~m} \times 1.37 \mathrm{~m} \times 1.37 \mathrm{~m})$ were erected in each pond with the support of bamboo poles. Individual net-cage, a fixed and fine-meshed nylon net enclosure, was fixed in such a way that one-third portion of the net-cage remained above the water surface to allow the surfacing of fish. The healthy and active IMCs, viz., C. catla $(22.03 \pm 0.91 \mathrm{~cm}$ and $150.61 \pm 16.38 \mathrm{~g})$, L. rohita $(19.73 \pm 1.46 \mathrm{~cm}$ and $101.40 \pm 16.60$ g) and C. mrigala $(22.46 \pm 1.03 \mathrm{~cm}$ and $121.64 \pm 24.82 \mathrm{~g})$ were stocked in each net-cage with 6 individuals of each species in the ratio 1:1:1, i.e., 18 fish/net-cage. The experimental fish were procured from Gangajoara, South 24 Parganas district, 
about five kilometres from the experimental site and acclimated for ten days in fibreglass reinforced plastic (500-L capacity) tanks containing $400-\mathrm{L}$ chlorine-free tap water. They were then transferred to experimental net cages and conditioned for 15 days. An additional net cage was also maintained with few individuals of each species in both the ponds for an emergency requirement, if any, during the conditioning. The fish were fed with commercial pellet feed containing $30 \%$ protein, $10 \%$ fat, $9 \%$ moisture, $32 \%$ carbohydrate and $9.5 \%$ ash at $3 \%$ of the bodyweight twice daily.

\section{Analysis of Water Quality Parameters}

The temperature of the pond water was recorded by a centigrade thermometer at the time of sampling usually between 8.00 and $9.00 \mathrm{am}$. The $\mathrm{pH}$ of water samples was estimated by $\mathrm{pH}$ meter (Eutech Instruments Pte Ltd). Total dissolved solids (TDS) were measured by TDS meter (HiMedia, India) and expressed as $\mathrm{mg} / \mathrm{L}$. The water quality parameters such as total hardness, dissolved oxygen (DO), free carbon dioxide $\left(\mathrm{CO}_{2}\right)$, biological oxygen demand (BOD), phosphate-phosphorous and ammonia-nitrogen were measured fortnightly following the standard methods (APHA/AWWA/WEF 2005).

\section{Collection of Fish Blood and Serum}

For blood collection, the fish $(n=6)$ from each net-cage were randomly sampled during the winter (December-February) and summer (March-June) months, transferred to plastic containers of $100-\mathrm{L}$ capacity containing water of the same temperature with added clove oil $(30 \mu \mathrm{L} / \mathrm{L})$ to reduce the activity of fish. The experimental fish were starved for $24 \mathrm{~h}$ before the blood collection to minimize the physiological stress during sampling. The blood was drawn using a $2 \mathrm{~mL}$ sterile disposable plastic syringe by the caudal venous puncture. For serum collection, the blood (min: $0.5 \mathrm{~mL}$ and max: 1.5 $\mathrm{mL}$ /fish) was collected from six individual fish of each replicate for each species of the NP and SP. The blood was allowed to clot overnight at $4^{\circ} \mathrm{C}$ by keeping the syringes at a $15^{\circ}$ angle. Serum from the syringes was then carefully poured out into Eppendorf tubes and centrifuged in a microfuge at $2500 \times \mathrm{g}$ for $10 \mathrm{~min}$. The serum samples of six fish from each of the replicate were pooled separately $(\geq 1.0 \mathrm{~mL}$ serum/tube), labelled and stored at $-20^{\circ} \mathrm{C}$ until use. Simultaneously, a portion of the blood sample from each species was transferred to $1.5 \mathrm{~mL}$ Eppendorf tubes rinsed with an anticoagulant (trisodium citrate, $3.8 \% \mathrm{w} / \mathrm{v}$ ) to prevent clotting. It was used for the estimation of haemoglobin by the acid-haematin method using Sahli's haemoglobinometer (Wintrobe, 1975) as a secondary stress response.

\section{Serum Biomarkers as Stress Responses}

The details on the analysis of various serum biomarkers such as glucose, cortisol, total protein, creatinine, alanine aminotransferase (ALT), aspartate aminotransferase (AST), lactate dehydrogenase (LDH) and superoxide dismutase (SOD) are summarized in Table 1 . The serum cortisol, as a primary stress response, was determined by using an ELISA based cortisol test kit (AccuBind Elisa Microwells, Cortisol test system, Monobind Inc, Lake Forest, USA). As secondary stress responses, parameters such as serum glucose, total protein, creatinine, ALT, AST, and LDH were determined by using standard kits in a Photometer (Model: 5010 v5+, Robert Riele KG, Berlin). The SOD levels as an indicator of oxidative stress were determined by using the SOD assay kit (Cayman Chemical, USA). All kits were used as per the manufacturer's protocol.

\section{Assessment of Fish Health}

The health status of experimental fish was evaluated as a tertiary response. On the day of routine monthly sampling or harvesting time during the winter and summer seasons, live IMCs from the SP $(n=327)$ and NP $(n=225)$ were also assessed for the frequency of ectoparasitic infection due to Lernaea, Argulus, myxosporeans and skin and gill flukes (Banerjee et al., 2015). The gills from each carp were removed with the least damage and placed for examination in separate Petri dishes containing filtered water. The gills were examined under a microscope for the presence of gill flukes or various types of plasmodia for myxosporean infection. Likewise, the skin scrapings from the caudal peduncle or tail, under the chin and behind the fins were placed on the slide and microscopically examined. The presence of cutaneous haemorrhages on each of the sampled fish was also noted visually. The parasitic frequency index (PFI) in percentage was calculated by taking the number of carps infected with at least one of the individual ectoparasites, against the total number of carps examined. The severity of infection was determined using the following scale: $0=$ no signs of ectoparasites, $0.5=$ a very few scattered signs of ectoparasitic infection; $1=$ low ectoparasitic infection; 2 low to moderate ectoparasitic infection, $3=$ moderate ectoparasitic infection, $4=$ severe ectoparasitic infection (Banerjee et al., 2015). 
Table 1. Kits and methods followed for the analysis of fish serum biomarkers

\begin{tabular}{|c|c|}
\hline Parameters & Kits used and methods followed \\
\hline $\begin{array}{l}\text { Alanine ami- } \\
\text { notransferase } \\
(\mathrm{ALT})^{*}\end{array}$ & $\begin{array}{l}\text { Modified UV (IFCC) and kinetic assay } \\
\text { methods, DiaSys Diagnostics Systems, } \\
\text { GmbH, Germany }\end{array}$ \\
\hline $\begin{array}{l}\text { Aspartate ami- } \\
\text { notransferase } \\
(\mathrm{AST})^{*}\end{array}$ & $\begin{array}{l}\text { Modified UV (IFCC) and kinetic assay } \\
\text { methods, DiaSys Diagnostics Systems, } \\
\text { GmbH, Germany }\end{array}$ \\
\hline Cortisol** & $\begin{array}{l}\text { AccuBind Elisa Microwells, Cortisol test } \\
\text { system, Monobind Inc, Lake Forest, } \\
\text { USA }\end{array}$ \\
\hline Creatinine* & $\begin{array}{l}\text { Modified Jaffe's reaction, Initial rate as- } \\
\text { say method, DiaSys Diagnostics Systems, } \\
\text { GmbH, Germany }\end{array}$ \\
\hline Glucose* & $\begin{array}{l}\text { GOD-FS method, DiaSys Diagnostics } \\
\text { Systems, GmbH, Germany }\end{array}$ \\
\hline $\begin{array}{l}\text { Lactate dehydro- } \\
\text { genase (LDH)* }\end{array}$ & $\begin{array}{l}\text { Modified IFCC method, DiaSys Diag- } \\
\text { nostics Systems, GmbH, Germany }\end{array}$ \\
\hline $\begin{array}{l}\text { Superoxide dis- } \\
\text { mutase (SOD)** }\end{array}$ & $\begin{array}{l}\text { Elisa Microwells, SOD test system, Cay- } \\
\text { man Chemical, USA }\end{array}$ \\
\hline Total protein* & $\begin{array}{l}\text { Biuret method, DiaSys Diagnostics Sys- } \\
\text { tems, GmbH, Germany }\end{array}$ \\
\hline
\end{tabular}

\section{Statistical Analyses}

A $2 \times 3 \times 2$ three-way analysis of variance (ANOVA) was performed by R statistical software version 3.4.1 to assess the effect of three factors namely ponds, species and seasons, and their interaction followed by Duncan's new multiple range test (DMRT). Data on PFI and cutaneous haemorrhages were analyzed by two-way ANOVA and DMRT. Student ' $t$ ' test was used to find out the significance of the difference between the water quality parameters of normal and sewage fed ponds in the Microsoft Excel package.

\section{Results and Discussion}

\section{Water Quality Parameters}

From the farm records, the minimum and maximum water temperatures during the study period were noted as 8 and $32^{\circ} \mathrm{C}$, respectively with a mean of $12.70 \pm 2.10^{\circ} \mathrm{C}$ in winter and $28.20 \pm 2.70^{\circ} \mathrm{C}$ in summer. The results of the physicochemical parameters of the SP and NP water samples are presented in Table 2 . The water quality parameters such as $\mathrm{pH}$, temperature, $\mathrm{DO}$ and free $\mathrm{CO}_{2}$ did not vary much between the normal and sewage-fed ponds. Although the level of free $\mathrm{CO}_{2}$ was high in the SP, the differences were insignificant $(p>0.05)$. On the other hand, the levels of total hardness, total dissolved solids and phosphate-phosphorous of the NP and SP exhibited significant differences $(p>0.05)$. The differences between the BOD as well as ammonia-nitrogen of the two systems were significant only at $\mathrm{p}<0.09$.

\section{Primary Stress Response}

The IMCs of SP recorded mean serum cortisol levels of 50.43 $\pm 6.00 \mu \mathrm{g} / \mathrm{dL}$; while those of NP had $51.70 \pm 3.23 \mu \mathrm{g} / \mathrm{dL}$ during the study period. There existed insignificant differences in the serum cortisol levels among the carps and ponds $(\mathrm{p}>0.05)$. The mean serum cortisol levels of the carps were significantly higher in winter $(52.49 \pm 3.43 \mu \mathrm{g} / \mathrm{dL})$ than in summer $(49.65 \pm 5.60 \mu \mathrm{g} / \mathrm{dL})$. The mean serum cortisol levels of $C$. mrigala were insignificantly higher ( $\mathrm{p}>0.05)$ than $L$. rohita and C. catla (Table 3).

Table 2. Ranges (mean \pm standard deviation (SD)) of physicochemical parameters of sewage-fed and normal fish pond waters

\begin{tabular}{lll}
\hline Water parameters & Normal pond: Range $($ Mean \pm SD) & Sewage-fed pond: Range $($ Mean \pm SD) \\
\hline $\mathrm{pH}$ & $7.20-7.90(7.57 \pm 0.18)$ & $7.20-7.80(7.51 \pm 0.18)$ \\
Temperature $\left({ }^{\circ} \mathrm{C}\right)$ & $13.00-32.00(23.17 \pm 3.27)$ & $13.00-32.00(22.54 \pm 3.43)$ \\
Dissolved oxygen $(\mathrm{mg} / \mathrm{L})$ & $4.00-8.80(7.69 \pm 1.31)$ & $6.00-8.54(7.09 \pm 0.68)$ \\
Free carbon dioxide $(\mathrm{mg} / \mathrm{L})$ & $0.00-16.00(8.08 \pm 6.75)$ & $8.00-20.00(13.27 \pm 5.21)$ \\
Total hardness $(\mathrm{mg} / \mathrm{L})$ & $180.00-360.00(294.63 \pm 55.81)^{\mathrm{a}}$ & $140.00-300.00(250.50 \pm 54.77)^{\mathrm{a}}$ \\
Total dissolved solids $(\mathrm{mg} / \mathrm{L})$ & $296.00-604.00(465.08 \pm 107.89)^{\mathrm{a}}$ & $200.00-351.00(264.58 \pm 41.08)^{\mathrm{a}}$ \\
Biological oxygen demand $(\mathrm{mg} / \mathrm{L})$ & $4.00-7.20(5.68 \pm 0.97)^{\mathrm{b}}$ & $4.10-8.30(6.95 \pm 1.46)^{\mathrm{b}}$ \\
Phosphate-phosphorous $(\mathrm{mg} / \mathrm{L})$ & $0.03-0.24(0.10 \pm 0.08)^{\mathrm{a}}$ & $0.17-0.61(0.35 \pm 0.17)^{\mathrm{a}}$ \\
Ammonia-nitrogen $(\mathrm{mg} / \mathrm{L})$ & $0.15-0.35(0.25 \pm 0.06)^{\mathrm{b}}$ & $0.30-0.93(0.48 \pm 0.20)^{\mathrm{b}}$ \\
\hline
\end{tabular}

Values are the average of 10 observations recorded during the study period. a: Values sharing common alphabets within the row for each of the parameters differ significantly $(\mathrm{p}<0.05)$; b: Significant at $\mathrm{p}<0.09$. 
Table 3. Mean values of blood and serum biomarkers of the cultured Indian major carps

\begin{tabular}{|c|c|c|c|c|c|c|c|}
\hline \multirow[t]{2}{*}{ Parameter } & \multicolumn{3}{|l|}{ Carps } & \multicolumn{2}{|l|}{ Ponds } & \multicolumn{2}{|l|}{ Seasons } \\
\hline & Catla catla & Labeo rohita & $\begin{array}{l}\text { Cirrhinus } \\
\text { mrigala }\end{array}$ & Sewage-fed & Normal & Summer & Winter \\
\hline Cortisol $(\mu \mathrm{g} / \mathrm{dL})$ & $49.55 \pm 6.34^{1}$ & $51.23 \pm 4.40^{1}$ & $52.43 \pm 2.85^{1}$ & $51.70 \pm 3.23^{\mathrm{a}}$ & $50.43 \pm 6.00^{\mathrm{a}}$ & $49.65 \pm 5.60^{\mathrm{A}}$ & $52.49 \pm 3.43^{\mathrm{B}}$ \\
\hline Haemoglobin $(\mathrm{g} / d L)$ & $5.14 \pm 0.83^{1}$ & $4.56 \pm 0.83^{2}$ & $5.47 \pm 0.96^{1}$ & $5.31 \pm 0.83^{\mathrm{a}}$ & $4.80 \pm .99^{b}$ & $5.39 \pm 0.93^{\mathrm{A}}$ & $4.73 \pm 0.84^{\mathrm{B}}$ \\
\hline Glucose (mg/dL) & $48.61 \pm 14.06^{1}$ & $48.94 \pm 20.72^{1}$ & $46.75 \pm 17.77^{1}$ & $39.12 \pm 12.28^{\mathrm{a}}$ & $57.08 \pm 17.38^{b}$ & $41.85 \pm 12.71^{\mathrm{A}}$ & $54.35 \pm 19.42^{\mathrm{B}}$ \\
\hline Total protein $(\mathrm{g} / \mathrm{dL})$ & $3.47 \pm 0.60^{1}$ & $3.62 \pm 1.01^{1}$ & $3.57 \pm 0.74^{1}$ & $3.91 \pm 0.80^{\mathrm{a}}$ & $3.20 \pm 0.59^{b}$ & $3.72 \pm 0.76^{\mathrm{A}}$ & $3.39 \pm 0.79^{\mathrm{A}}$ \\
\hline Creatinine (mg/dL) & $0.40 \pm 0.08^{1}$ & $0.41 \pm 0.06^{1}$ & $0.53 \pm 0.24^{2}$ & $0.40 \pm 0.07^{\mathrm{a}}$ & $0.48 \pm 0.21^{b}$ & $0.38 \pm 0.07^{\mathrm{A}}$ & $0.51 \pm 0.21^{\mathrm{B}}$ \\
\hline $\begin{array}{l}\text { Alanine aminotransferase } \\
\text { (IU/L) }\end{array}$ & $15.60 \pm 8.19^{1}$ & $13.7 \overline{5} \pm 7.93^{1}$ & $11.55 \pm 5.94^{1}$ & $11.86 \pm 6.95^{\mathrm{a}}$ & $15.40 \pm 7.69^{\mathrm{b}}$ & $10.13 \pm 2.66^{\mathrm{A}}$ & $17.13 \pm 9.03^{\mathrm{B}}$ \\
\hline $\begin{array}{l}\text { Aspartate aminotransferase } \\
\text { (IU/L) }\end{array}$ & $84.35 \pm 33.59^{1}$ & $97.35 \pm 27.55^{2}$ & $96.00 \pm 29.84^{12}$ & $80.83 \pm 30.38^{\mathrm{a}}$ & $104.30 \pm 26.12^{\mathrm{b}}$ & $75.31 \pm 24.07^{\mathrm{A}}$ & $\begin{array}{l}109.81 \\
\pm 26.37^{\mathrm{B}}\end{array}$ \\
\hline $\begin{array}{l}\text { Lactate dehydrogenase } \\
\text { (U/L) }\end{array}$ & $68.12 \pm 10.18^{1}$ & $68.75 \pm 12.40^{1}$ & $76.60 \pm 13.26^{2}$ & $71.35 \pm 9.35^{\mathrm{a}}$ & $70.96 \pm 15.09^{a}$ & $68.25 \pm 12.86^{\mathrm{A}}$ & $74.07 \pm 11.51^{\mathrm{A}}$ \\
\hline $\begin{array}{l}\text { Superoxide dismutase } \\
(\mathrm{U} / \mathrm{mL})\end{array}$ & $49.41 \pm 16.57^{1}$ & $49.15 \pm 7.91^{1}$ & $56.31 \pm 16.20^{1}$ & $53.93 \pm 10.64^{\mathrm{a}}$ & $49.31 \pm 17.07^{\mathrm{a}}$ & $47.51 \pm 15.25^{\mathrm{A}}$ & $55.73 \pm 12.17^{\mathrm{B}}$ \\
\hline
\end{tabular}

\section{Secondary Stress Responses}

The results of the biomarkers of secondary stress responses are presented in Table 3. Catla catla, L. rohita and C. mrigala recorded mean haemoglobin levels of $5.14 \pm 0.83,4.56 \pm 0.83$ and $5.47 \pm 0.96 \mathrm{~g} / \mathrm{dL}$, respectively. There existed significant differences $(p>0.05)$ in the mean haemoglobin levels among the carps, seasons and ponds. The carps of the SP had significantly lower haemoglobin levels $(p>0.05)$. The haemoglobin levels of carps were significantly high in summer $(\mathrm{p}>0.05)$. Among the carps, L. rohita had significantly lower ( $>0.05)$ haemoglobin levels. Serum glucose levels of C. catla, L. rohita and C. mrigala were $48.61 \pm 14.06,48.94 \pm 20.72$ and $46.75 \pm 17.77 \mathrm{mg} / \mathrm{dL}$. Significant differences existed in the glucose levels among the seasons and ponds $(\mathrm{p}<0.05)$, but not among the carps $(p>0.05)$. The serum glucose levels of the carps of the SP $(57.08 \pm 17.38 \mathrm{mg} / \mathrm{dL})$ as well as the winter season $(54.35 \pm 19.42 \mathrm{mg} / \mathrm{dL})$ were significantly higher $(\mathrm{p}<0.05)$. The serum total protein levels of the IMCs were in the range of $3.47 \pm 0.60-3.67 \pm 1.01 \mathrm{~g} / \mathrm{dL}$. The differences in the total serum protein levels among the carps as well as seasons were, however, insignificant $(\mathrm{p}>0.05)$. The carps of the $\mathrm{NP}$ had significantly higher $(\mathrm{p}<0.05)$ serum total protein levels. Labeo rohita recorded the highest mean serum total protein values. The serum creatinine values of IMCs ranged from $0.40 \pm 0.08 \mathrm{mg} / \mathrm{dL}$ in $C$. catla to $0.53 \pm 0.24 \mathrm{mg} / \mathrm{dL}$ in $C$. mrigala. The carps of the SP $(0.48 \pm 0.21 \mathrm{mg} / \mathrm{dL})$ and those sampled during the winter $(0.51 \pm 0.21 \mathrm{mg} / \mathrm{dL})$ recorded significantly higher creatinine levels $(\mathrm{p}<0.05)$. There existed significant differences in the serum creatinine levels among the carps, seasons and ponds $(\mathrm{p}<0.05)$. Cirrhinus mrigala recorded significantly higher serum creatinine levels $(\mathrm{p}<0.05)$. The serum ALT levels of the IMCs ranged from $11.55 \pm 5.94 \mathrm{IU} / \mathrm{L}$ in $C$. mrigala to $15.60 \pm 8.19 \mathrm{IU} / \mathrm{L}$ in $C$. catla. The carps of the SP $(15.40 \pm 7.69 \mathrm{mg} / \mathrm{dL})$ and those sampled during the winter $(17.13 \pm 9.03 \mathrm{mg} / \mathrm{dL})$ recorded significantly higher ALT levels $(\mathrm{p}<0.05)$. There existed significant differences in the serum ALT levels among the seasons and ponds $(\mathrm{p}<0.05)$, but not among the carps $(\mathrm{p}>0.05)$. The IMCs $C$. catla, L. rohita and C. mrigala recorded the serum AST levels of $84.35 \pm 33.59,97.35 \pm 27.55$ and $96.00 \pm 29.84$ IU/L, respectively. The serum AST levels of the carps of the $\mathrm{SP}(104.30 \pm 26.12 \mathrm{IU} / \mathrm{L})$ as well as the winter season $(109.81$ $\pm 26.37 \mathrm{IU} / \mathrm{L})$ were significantly higher $(\mathrm{p}<0.05)$. There existed significant differences in the serum AST levels among the carps, seasons and ponds $(\mathrm{p}<0.05)$. Labeo rohita recorded the highest mean serum AST levels. The mean serum LDH levels of the IMCs ranged from $68.12 \pm 10.18 \mathrm{U} / \mathrm{L}$ in $C$. catla to $76.60 \pm 13.26 \mathrm{U} / \mathrm{L}$ in $C$. mrigala. Significant differences existed in the serum LDH levels among the carps $(\mathrm{p}<0.05)$, but not among the seasons and ponds $(p>0.05)$. The carps of the NP and those sampled during the winter recorded high LDH levels, but the differences were insignificant ( $p>0.05)$.

\section{Oxidative Stress}

The serum SOD levels recorded in C. catla, L. rohita and $C$. mrigala were $49.41 \pm 16.57,49.15 \pm 7.91$ and $56.31 \pm 16.20$ $\mathrm{U} / \mathrm{mL}$, respectively (Table 3 ). The differences in the serum SOD levels among the carps and ponds were insignificant $(\mathrm{p}>0.05)$. Cirrhinus mrigala recorded the highest mean serum SOD levels. The carps recorded significantly higher serum SOD levels $(55.73 \pm 12.17 \mathrm{U} / \mathrm{mL})$ during the winter $(\mathrm{p}<0.05)$.

\section{Tertiary Stress Responses}

The results of the PFI and incidence of cutaneous haemorrhages in IMCs are presented in Figures 1 and 2, respectively. The PFI was more in L. rohita followed by C. catla and $C$. 
mrigala but the differences were insignificant $(\mathrm{p}>0.05)$. The differences in the PFI among the ponds and seasons were, however, significant (Figure 1; $<<0.05$ ). The frequency of infection and incidence of cutaneous haemorrhages was significantly more in the carps of the SP particularly during the winter (Figure $2 ; \mathrm{p}<0.05$ ). The severity of ectoparasitic infection was 0-2.0 in winter and 0-0.5 in summer in both the ponds.

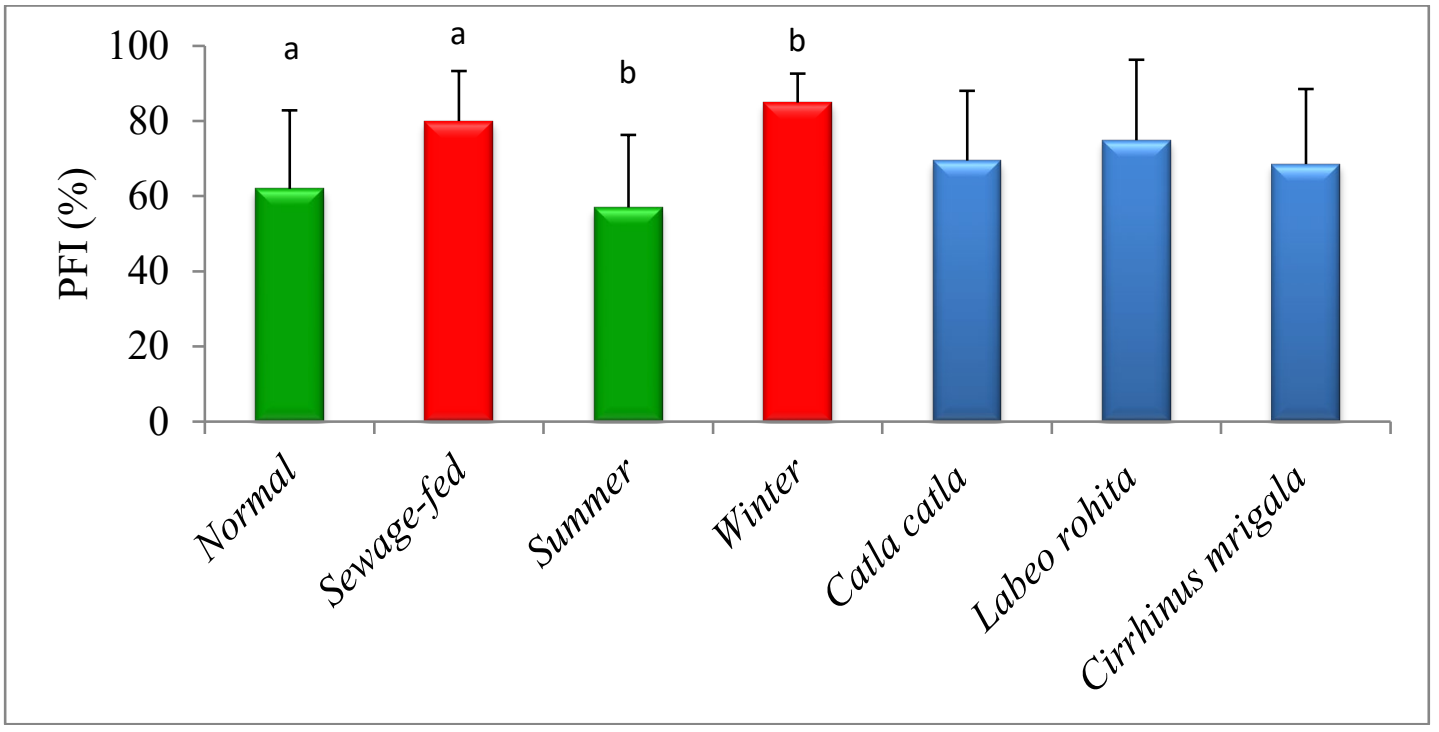

Figure 1. Parasitic frequency index (PFI) in Indian major carps cultured in sewage-fed and normal ponds. a,b: Bars sharing common alphabets differed significantly $(p<0.05)$.

$\mathrm{PFI}=\frac{\text { The number of carps infected with at least one of the individual ectoparasites }}{\text { The total number of carps examined }} \times 100$

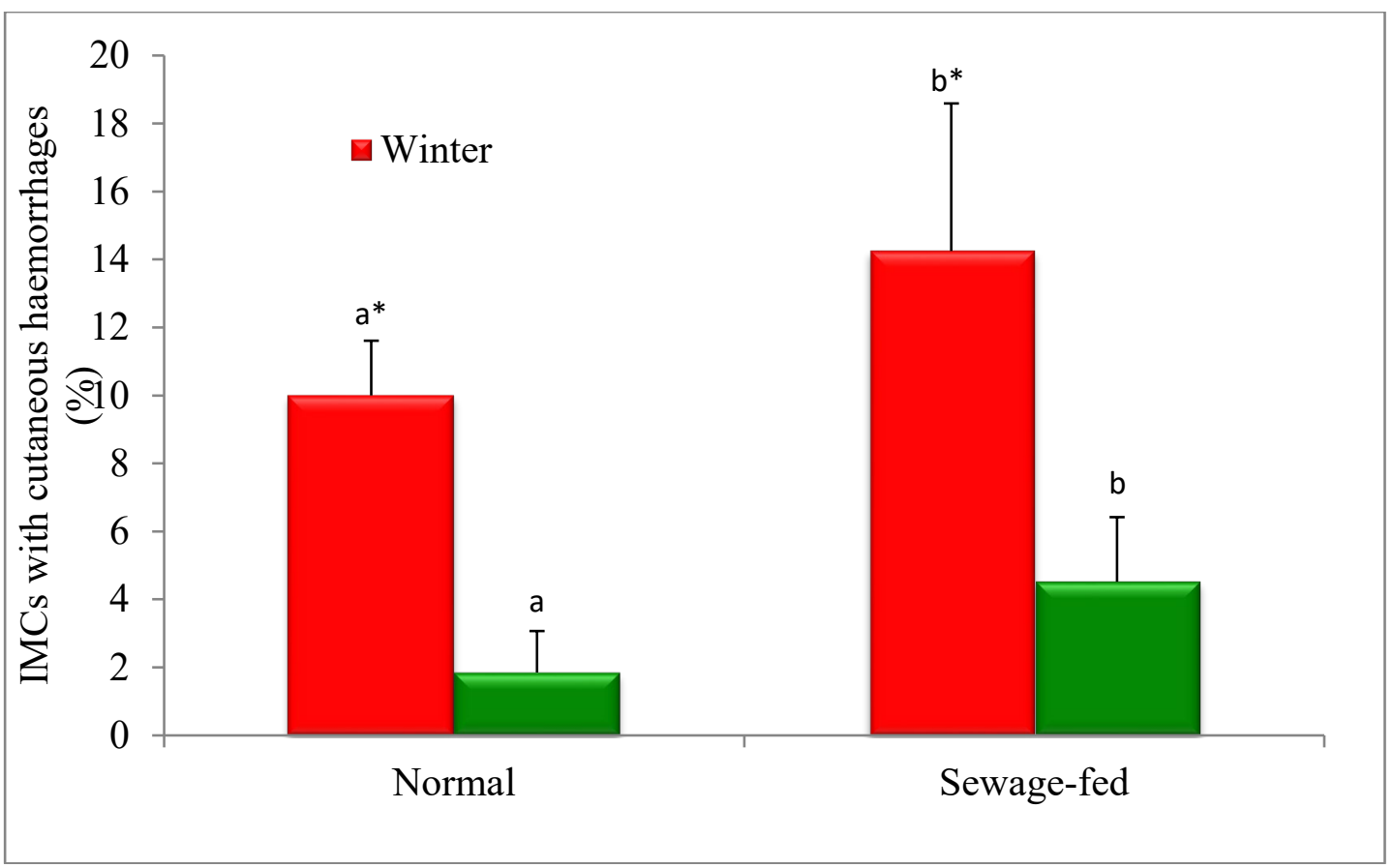

a,b, ${ }^{*}$ : Bars sharing common alphabets or the asterisk $(*)$ differed significantly $(p<0.05)$.

Figure 2. Indian major carps (IMCs) with cutaneous haemorrhages (in \%) from the sewagefed and normal ponds. 
The treatment of Kolkata metropolitan liquid waste is done by natural means through a network of canals in the peri-urban areas. This naturally treated wastewater is used for aquaculture in the EKW and the peri-urban areas without any further treatment (SWRE, 2007; Chatterjee et al., 2010; Sarkar et al., 2011; Banerjee et al., 2015). The untreated sewage from the feeder canal of the SP area was reportedly had $\mathrm{pH}$ 7.01-7.40, BOD 61-84 mg/L, TDS 370-415 mg/L, phosphate $1.28-1.98 \mathrm{mg} / \mathrm{L}$, ammonia $3.10-3.90 \mathrm{mg} / \mathrm{L}$ and nitrate $0.93-$ $3.90 \mathrm{mg} / \mathrm{L}$ (SWRE, 2007). The fish caught in these water bodies were found to accumulate chromium, copper, lead and other toxic elements in their flesh (Chatterjee et al., 2010; Sarkar et al., 2011). It is widely acknowledged that the physicochemical characteristics of the water influence the biological and physiological functions of fish and unsuitable water quality results in the activation of the stress responses (Bernet et al., 2000, 2001). In the present study, the water quality parameters recorded in the NP were well within the optimum range, except for the total hardness and BOD recommended for carps (Boyd, 1979). On the other hand, the water quality parameters of the SP fluctuated greatly and inconsistently, though few of them had higher levels. The SP of the present study also received untreated tannery waste, which possibly led to poor water quality, mainly due to the increase in ionic levels and organic pollution denoted by higher levels of BOD $(6.95 \pm 1.46 \mathrm{mg} / \mathrm{L})$, ammonia-nitrogen $(0.48 \pm 0.20 \mathrm{mg} / \mathrm{L})$, phosphate-phosphorous $(0.35 \pm 0.17 \mathrm{mg} / \mathrm{L})$ and free $\mathrm{CO}_{2}$ $(13.27 \pm 5.21 \mathrm{mg} / \mathrm{L})$. Compared to the levels recorded in the sewage feeder canal (SWRE 2007), the water quality parameters of the SP were quite low by about 6-12 folds, possibly due to the dilution of sewage in the pond environment. The observed high ammonia, phosphate-phosphorous and BOD levels in the water of the SP are an indication of eutrophic condition, which further hampers the fish homeostasis as multiple stressors.

In the present study, the carps of the SP had significantly higher haemoglobin levels. The highest haemoglobin level was observed in C. mrigala and the least in L. rohita. The higher haemoglobin content in the carps of the SP might be due to the increased demand for oxygen necessitated by the use of untreated sewage in the pond with high BOD as well as the use of tannery waste as feed. It infers that a small quantity of DO was utilized by the carps in the presence of high ammonia in the surrounding medium. Furthermore, significant differences in the haemoglobin levels of carps during the summer and winter seasons were noted, which corroborate the earlier study (Pradhan et al., 2014). They recorded a higher concentration of haemoglobin in L. rohita $(8.50 \mathrm{~g} / \mathrm{dL})$ in summer and the least $(5.50 \mathrm{~g} / \mathrm{dL})$ in winter. Likewise, higher haemoglobin levels were recorded in carps exposed to chemical stressors (Prusty et al., 2011), possibly due to the replacement of oxidized denatured haemoglobin by the toxic elements and to supply more oxygen to oxygen-deficient tissues (Nussey et al., 1995). The increase may also be attributed to the catalyzing action of toxicants on the incorporation of body iron stores into haemoglobin or increased erythropoiesis and haemoglobin synthesis (Prusty et al., 2011).

It is well known that the responses of fish to stress are cumulative. Under stressful conditions, the fish body release stress hormones, viz., cortisol and catecholamines into the bloodstream by the endocrine system as a primary response and produce increased levels of glucose as a secondary response (Martínez-Porchas et al., 2009; Sopinka et al., 2016). The results on the marked differences in the levels of serum cortisol among the carps corroborate the earlier observations (Dutta et al., 2005), who observed significant variations in the plasma cortisol $(90.0-377.0 \mathrm{ng} / \mathrm{mL})$ in fish reared in a sewage-fed farm than those reared in a farm having optimum water quality. Significant differences in the serum cortisol levels of carps, particularly L. rohita of the SP, were recorded between the seasons. The carps during the low-temperature period recorded significantly higher levels of serum cortisol, which, more or less, corroborate the previous observations (Das et al., 2009) made in carps with the increase in acclimation temperature from the optimal $\left(26^{\circ} \mathrm{C}\right)$ to $36^{\circ} \mathrm{C}$. In contrast, fish could display a "metabolic conservation" strategy with no cortisol increase, when the dose, duration and/or the number of stressors is high (Petitjean et al., 2019). The suitability of using circulating cortisol levels in the blood of chronically stressed fish has, therefore, been questioned (van Weerd and Komen, 1998). Our results on the serum cortisol suggested that the carps were chronically stressed, which was more pronounced during the winter season when grown in the SP. Besides, our insignificant results on the serum cortisol levels as stress biomarker of carp from the NP $(51.70+3.23 \mu \mathrm{g} / \mathrm{dL})$ and SP $(50.43+6.00 \mu \mathrm{g} / \mathrm{dL})$ provided supportive evidence to earlier reports (van Weerd and Komen, 1998). The results of the present study and the past studies (Martínez-Porchas et al., 2009; Petitjean et al., 2019) amply revealed that serum cortisol response would not be sufficient, but rather a less reliable tool to examine the stress status of chronically stressed carps.

The present study recorded significantly high levels of serum glucose in carps reared in the SP as well as winter season. The levels of glucose may vary in ecologically distinct species and are influenced by environmental and non-environmental factors (Sopinka et al., 2016). The differences in the serum glucose levels among the carps of the present study were insignificant, though the IMCs occupy different ecological niches of the pond. It has been reported that under stressful 
conditions the glucose production is mostly mediated by the action of cortisol (Sopinka et al., 2016). Several earlier workers also reported a rise in glucose levels of carps exposed to various kinds of stressors such as ammonia (Das et al., 2004a) and temperature (Das et al., 2009). Though there were differences in the glucose levels of carps between the ponds, the differences in the cortisol levels of carps from these systems were insignificant. These results indicated that there was no correlation between serum glucose and cortisol levels in chronically stressed carps exposed to sewage in EKW.

The levels of antioxidant enzymes including SOD have been extensively used as an early warning indicator of aquatic pollution (Birnie-Gauvin et al., 2017). SOD is the only antioxidant that detoxifies superoxide, dismutating it to hydrogen peroxide and oxygen (Kammer et al., 2011). The estimated antioxidant activity of SOD in carp blood was in the range of $3.20 \pm 0.01-5.02 \pm 0.30 \mathrm{U} / \mathrm{mL}$ (Valon et al., 2013), which was almost 12-18 times lower than the present study. The significant increase in the SOD activity of carp blood particularly during the winter season may be explained as a compensation mechanism against the stress factors. According to Kammer et al. (2011), the SOD activity may increase during low temperature to offset the depressive effects on the catalytic rate of the enzyme, rather than to defend against elevated levels of reactive oxygen species (ROS) production. Several earlier studies also reported elevated SOD activities in fish exposed to low temperatures (Pavlović et al., 2013; Birnie-Gauvin et al., 2017), possibly due to increased polyunsaturation of mitochondrial membranes and elevated mitochondrial respiration. Cirrhinus mrigala recorded the highest mean serum SOD activity $(56.31 \pm 16.20 \mathrm{U} / \mathrm{mL})$, by its bottom-dwelling behaviour and exposure to unhealthy pond bottom conditions. Also, the higher SOD activity in C. mrigala from the SP indicated that the enhanced production of superoxide radicals created oxidative stress in this species. It means that $C$. mrigala has better adaptive responses to protect its physiological system, counteract the oxidative effect of ROS and resist the pollutants on the pond bottom. Earlier studies also demonstrated that SOD activity increased after exposure to pollution in various fish (Zikić et al., 2002; Sopinka et al., 2016). In general, the results of the stress biomarkers such as serum cortisol and SOD provided inconclusive evidence on the effect of long-term exposure of sewage on carps. On the other hand, the effect of seasonal pond water temperature on the stress biomarkers such as glucose, cortisol and SOD was more evident, where their levels were always and significantly higher during the winter.

The carps of the NP had significantly higher serum total protein levels. Similar to the present study, many researchers recorded a reduction in total protein levels when the carps were subjected to stressors (Das et al., 2004a,b). The plasma protein may decrease due to alteration in enzymatic activity involved in protein biosynthesis (Sopinka et al., 2016), a high degree of haemodilution under the stress conditions (BurgosAceves et al., 2019), shrinkage and lysis of RBC causing plasma dilution and/or protein catabolism (Das et al., 2004b), increased effects on the fish immune system, and liver disorders (Nayak et al., 2004). The observed reduction in fish serum protein levels of the present study may be attributed to their possible utilization for energy fulfilment. The carps of the NP and those sampled during the summer recorded significantly lower serum creatinine levels. The results of the present study on elevated serum creatinine levels of carps cultured in the SP or during the winter corroborate the observations of the earlier studies upon exposure to various stressors and effluent from the sewage treatment units (Bernet et al., 2000, 2001). They reported Salmo trutta exposed to effluent from the sewage treatment unit had significantly different alkaline phosphatase, blood urea nitrogen, creatinine and bilirubin values than the fish kept in river water. Increased level of serum creatinine is an indication of kidney dysfunction, and physical exertion of organisms (Bernet et al., 2001; Outtandy et al., 2019), which was more pronounced in the bottom-dwelling C. mrigala from the SP. Possibly, the unfavourable pond bottom condition might have favoured dysfunction of C. mrigala kidney. The farmers of the sewage-fed farms of the surrounding area expressed that the growth of $C$. mrigala was poor compared to other carps.

Liver enzymes (ALT, AST and LDH) are the most suitable variables in fish as indicators of water with a high organic load like sewage water. Acceptable reference intervals of cyprinids as 9-23 IU/L for ALT (Nicula et al., 2010) corresponded well with the carps of the NP or in summer. While the carps of the SP recorded significantly high levels of ALT. The results of the present study corroborate several earlier observations recorded on carps (Prusty et al., 2011), goldfish (Simmons et al., 2017) and trout (Bernet et al., 2001) exposed to chemical stressors and sewage effluent. The levels of AST recorded in the carps of the present study were almost 2-4 times the acceptable reference level of cyprinid, i.e., 26-54 IU/L (Nicula et al., 2010). Teleosts are known for their ability to convert amino acids into glucose (Rodwell, 1988). Therefore, the higher activities of AST and ALT indicated the mobilization of aspartate and alanine via gluconeogenesis for glucose production to cope with stress. It may be noted here that glucose and protein levels recorded in the present study differed significantly due to ponds and seasons. Under the effect of oxidative stress, which was confirmed by high SOD levels, there may be an increase in AST and ALT activities and a greater degree of hepatic dysfunction (Nayak et al., 2004). Generally, the levels of ALT and AST were high in 
carps of the SP, which correlated well with the decrease in serum protein level, thus confirming the role of protein in metabolism, possibly as a compensatory mechanism to the impaired metabolism (Simmons et al., 2017). Further, it is noteworthy to mention here that dysfunction of the carp liver has been noticed in the form of elevated ALT and AST levels both in the SP and NP, most likely due to the stress induced by the winter temperature and/or microbial infection. In contrast, some researchers reported a significant decrease in AST and ALT activities during acute and sublethal treatment of pollutant, which they have attributed to severe damage of hepatocytes that are no longer capable of synthesizing AST protein. Renal failure may also contribute to a significant decrease in ALT activity (Kavitha et al., 2010).

In the present study, the highest LDH values were observed in C. mrigala of the SP followed by L rohita and C. catla. The carps during the winter season recorded higher serum LDH levels. Likewise, a significant increase in the LDH activity was observed in carps exposed to different stressors such as sewage (Bernet et al., 2000, 2001), suboptimal temperature (Chatterjee et al., 2004) and high ammonia (Das et al., 2004a). Interestingly, C. catla and L. rohita of the SP recorded slightly lower LDH levels than those from the NP. Similar to this study, a reduced LDH activity in fish exposed to toxicants was noted (Mishra and Shukla, 2003), possibly due to the higher glycolysis rate under stressful conditions. Nevertheless, the observed insignificant differences in the serum LDH levels among the seasons and ponds suggested that the $\mathrm{LDH}$ is a less reliable biomarker to assess the stress status of chronically stressed IMCs. The application of serum chemistry variables as indicators of histological lesions in case of chronic exposure is questionable (Bernet et al., 2001).

During the culture period, infections due to ectoparasites (Lernaea, Argulus, skin flukes and myxosporeans), and cutaneous haemorrhages were observed in IMCs of both the ponds in January, February and the first week of March, which coincided with the mid and late winter. Labeo rohita was the most susceptible to parasitic infection followed by $C$. catla and C. mrigala. The carps of the SP had a high degree of ectoparasitic infection. Effluents from the sewage treatment units affect fish health, causing histological lesions and higher susceptibility to infectious diseases has been well demonstrated (Petitjean et al., 2019; Bernet et al., 2000, 2001) which also corroborates with the present study. Our results also indicated that the sewage-fed aquaculture in EKW had a detrimental impact on the health of carps by enhancing the stress responses and their susceptibility to microbial infection. The infection due to the microbial agents and the temperature stress during the winter season could be the probable reason for the insignificant differences observed in many of the serum biochemical parameters. Due to low water temperature and microbial infection, fish mortalities in net-cages ranging from nil in summer to $11 \%$ in winter were recorded. The increased susceptibility to disease could also be attributed to the confinement in the net-cages and the multiple stressors. Besides, growth retardation and production loss were recorded in the SP so also in an earlier study to the tune of $13 \pm 4 \%$ (Banerjee et al., 2015, 2017). Also, the involvement of heavy metals and other toxicants present in the sewage (SWRE, 2007, Chatterjee et al., 2010; Sarkar et al., 2011) on the elevated levels of serum biochemical indices could not be ruled out. In West Bengal aquaculture, the factors like the use of sewage water, poor pond bottom conditions and low temperature were identified as putative as they increased the chance of occurrence of infectious diseases (Abraham et al., 2020).

\section{Conclusion}

In general, the present study revealed that the winter temperature $\left(12.70 \pm 2.10^{\circ} \mathrm{C}\right)$ and the chronic exposure of IMCs to sewage in EKW elevated the stress levels of carps. The results of the stress biomarkers such as cortisol and SOD provided inconclusive evidence for their usefulness as suitable biomarkers on the effect of long-term exposure of sewage on carps. On the other hand, the effect of seasonal water temperature on the stress biomarkers such as glucose, cortisol and SOD was more evident, where their levels were always and significantly high during the winter. Our results on the increasing levels of serum glucose, creatinine, ALT and/or AST suggested that these indices, which were more pronounced in a sewage-fed pond in EKW in conjunction with low water temperature, could be useful biomarkers of stress, kidney and liver functioning of carps, respectively. Although these in situ studies provided some insights into the stress responses and serum biomarkers of IMCs cultured in the EKW, further investigations on the fish immune status, carp-microbial interactions, genetic/resistance markers and epigenetic responses of carps to environmental stressors are needed to evolve suitable management strategies for the sustainable aquaculture activities in such system.

\section{Compliance with Ethical Standard}

Conflict of interests: The authors declare that for this article they have no actual, potential or perceived conflict of interests.

Ethics committee approval: All applicable guidelines of the "Committee for the Purpose of Control and Supervision of Experiments on Animals" (CPCSEA), Government of India, New Delhi were followed by the authors. The conventional regulatory framework may not be applied regarding the use of experimental animals in agricultural production research as per the guidelines of the 
"Committee for the Purpose of Control and Supervision of Experiments on Animals", Government of India and, hence, Ethical Committee approval wasn't needed. All efforts were also made to minimize the suffering of the animals during the experimentation.

Funding disclosure: The research work was supported by the Indian Council of Agricultural Research, Government of India, New Delhi under the Niche Area of Excellence programme vide Grant F. 10(12)/2012-EPD dated 23.03.2012.

Acknowledgments: The authors thank the Vice-Chancellor, West Bengal University of Animal and Fishery Sciences, Kolkata for providing the necessary infrastructure facilities to carry out the work. Statistical advice received by Mr T.S. Vishwanath, Assistant Director of Fisheries, Department of Fisheries, Government of Karnataka, Bangalore is gratefully acknowledged. The help rendered by Mr Shivraj Singh and his associates of the sewage-fed fish farm during the entire experimental period is gratefully acknowledged.

Disclosure: -

\section{References}

Abraham, T.J., Sil, S.K., Vineetha, P. (2010). A comparative study of the aquaculture practices adopted by fish farmers in Andhra Pradesh and West Bengal. Indian Journal of Fisheries, 57(3), 41-48.

Abraham, T.J., Sil, S.K., Nagesh, T.S. (2020). Association of risk factors and management issues on the occurrence of diseases in carp aquaculture in West Bengal, India. Proceedings of the Zoological Society, 73, 243-250.

https://doi.org/10.1007/s12595-020-00325-7

APHA/AWWA/WEF (2005). Standard Methods for the Examination of Water and Waste Water. $12^{\text {th }}$ edn. Washington: American Public Health Association, American Water Works Association and Water Environment Federation, USA.

Banerjee, S., Dash, G., Abraham, T.J. (2015). Histopathology of gill myxosporean infection in cultured Indian major and minor carps, West Bengal, India. Journal of Applied Ichthyology, 31(6), 1137-1141.

https://doi.org/10.1111/jai.12917

Banerjee, S., Patra, A., Mondal, A., Adikesavalu, H., Ramudu, K.R., Dash, G., Joardar, S.N., Abraham, T.J. (2017). Molecular characterization of Myxobolus catmrigalae (Myxosporea: Myxobolidae) infecting the gill lamellae of carp Cirrhinus mrigala (Hamilton). Journal of Parasitic Diseases, 41, 62-70.

https://doi.org/10.1007/s12639-016-0750-0
Bernet, D., Schmidt-Posthaus, H., Wahli, T., BurkhardtHolm, P. (2000). Effects of wastewater on fish health: an integrated approach to biomarker responses in brown trout (Salmo trutta L.). Journal of Aquatic Ecosystem Stress and Recovery, 8(2), 143-151.

https://doi.org/10.1023/A:1011481632510

Bernet D., Schmidt H., Wahli T., Burkhardt-Holm P. (2001). Effluent from a sewage treatment works causes changes in serum chemistry of brown trout (Salmo trutta). Ecotoxicology and Environmental Safety, 48(2), 140-147. https://doi.org/10.1006/eesa.2000.2012

Bhowmik, M.L. (2011). Wastewater aquaculture. In: Ayyappan, S., Jena, J.K., Gopalakrishnan, A., Pandey, A.K., (eds) Handbook of fisheries and aquaculture. New Delhi: Indian Council of Agricultural Research, pp. 320-334.

Birnie-Gauvin, K., Costantini, D., Cooke, S.J., Willmore, W.G. (2017). A comparative and evolutionary approach to oxidative stress in fish: A review. Fish and Fisheries, 18(5), 928-942.

https://doi.org/10.1111/faf.12215

Boyd, C.E. (1979). Water quality in warm water fish ponds. Agriculture Experiment Station, Alabama: Auburn.

Burgos-Aceves, M.A., Lionetti, L., Faggio, C. (2019). Multidisciplinary haematology as prognostic device in environmental and xenobiotic stress-induced response in fish. Science of the Total Environment, 670, 1170-1183. https://doi.org/10.1016/j.scitotenv.2019.03.275

Chatterjee, N., Pal, A.K., Manush, S.M., Das, T., Mukherjee, S.C. (2004). Thermal tolerance and metabolic status of Labeo rohita and Cyprinus carpio early fingerlings acclimated to three different temperatures. Journal of Thermal Biology, 29(6), 265-270.

https://doi.org/10.1016/j.jtherbio.2004.05.001

Chatterjee, S., Chattopadhyay, B., Mukhopadhyay, S.K. (2010). Monitoring waste metal pollution at Ganga estuary via the East Calcutta Wetland areas. Environmental Monitoring Assessment, 170(1-4), 23-31.

https://doi.org/10.1007/s10661-009-1211-3

Chitra-Pakhira, Nagesh, T.S., Abraham, T.J., Dash, G., Behera, S. (2015). Stress responses in rohu, Labeo rohita transported at different densities. Aquaculture Reports, 2, 39-45.

https://doi.org/10.1016/j.aqrep.2015.06.002 
Das, P.C., Ayyappan, S., Jena, J.K., Das, B.K. (2004a). Acute toxicity of ammonia and its sub-lethal effects on selected haematological and enzymatic parameters of mrigal, Cirrhinus mrigala (Hamilton). Aquaculture Research, 35(2), 134-143.

https://doi.org/10.1111/j.1365-2109.2004.00994.x

Das, P.C., Ayyappan, S., Jena, J.K., Das, B.K. (2004b). Nitrite toxicity in Cirrhinus mrigala (Ham.), acute toxicity and sub-lethal effect on selected haematological parameters. $A q$ uaculture, 235(1-4), 633-644.

https://doi.org/10.1016/j.aquaculture.2004.01.020

Das, T., Pal, A.K., Chakraborty, S.K., Manush, S.M., Dalvi, R.S., Apte, S.K., Sahu, N.P., Baruah, J.K. (2009). Biochemical and stress responses of rohu Labeo rohita and mrigal Cirrhinus mrigala in relation to acclimation temperatures. Journal of Fish Biology, 74(7), 1487-1498.

https://doi.org/10.1111/j.1095-8649.2009.02216.x

Dutta, T., Acharya, S., Das, M.K. (2005). Impact of water quality on the stress physiology of cultured Labeo rohita (Hamilton-Buchanan). Journal of Environmental Biology, 26(3), 585-592.

EKWMA (2010). East Kolkata Wetlands. Newsletter, Vol 1. The East Kolkata Wetlands Management Authority and Wetlands International-South Asia, India, p.24, Available at http://www.ekwma.in/ek/wp-content/up-

loads/2015/09/NewsletterVolume1.pdf

Kavitha, C., Malarvizhi, A., Kumaran, S.S., Ramesh, M. (2010). Toxicological effects of arsenate exposure on hematological, biochemical and liver transaminases activity in an Indian major carp, Catla catla. Food and Chemical Toxicology, 48(10), 2848-2854.

https://doi.org/10.1016/j.fct.2010.07.017

Martínez-Porchas, M., Martínez-Córdova, L.R., RamosEnriquez, R. (2009). Cortisol and glucose: reliable indicators of fish stress?. Pan-American Journal of Aquatic Sciences, 4(2), 158-178.

Mishra, R., Shukla, S.P. (2003). Endosulfan effects on muscle malate dehydrogenase of the freshwater catfish Clarias batrachus. Ecotoxicology and Environmental Safety, 56(3), 425-433.

https://doi.org/10.1016/S0147-6513(03)00006-X
Nayak, A.K., Das, B.K., Kohli, M.P.S., Mukherjee, S.C. (2004). The immunosuppressive effect of $\alpha$-permethrin on Indian major carp, rohu (Labeo rohita Ham.). Fish and Shellfish Immunology, 16(1), 41-50.

https://doi.org/10.1016/S1050-4648(03)00029-9

Nicula, M., Bura, M., Simiz, E., Banatean-Dunea, I., Patruica, S., Marcu, A., Lunca, M., Szelei, Z. (2010). Researches concerning reference values assessment of serum biochemical parameters in some fish species from Acipenseridae, Cyprinidae, Esocidae and Salmonidae family. Journal of Animal Science and Biotechnology, 43(1), 498-505.

Nussey, G., van Vuren, J.H., Du Preez, H.H. (1995). Effect of copper on blood coagulation of Oreochromis mossambicus (Cichlidae). Comparative Biochemistry and Physiology Part C: Pharmacology Toxicology and Endocrinology, 111(3), 359-367.

https://doi.org/10.1016/0742-8413(95)00062-3

Outtandy, P., Russell, C., Kleta, R., Bockenhauer, D. (2019). Zebrafish as a model for kidney function and disease. Pediatric Nephrology, 34, 751-762.

https://doi.org/10.1007/s00467-018-3921-7

Pavlović, S.Z., Borković-Mitić, S.S., Radovanović, T.B., Perendija, B.R., Despotović, S.G., Gavrić, J.P., Saičić, Z.S. (2013). Antioxidant enzymes in the liver of Chelidonichthys obscurus from the Montenegrin coastline. Central European Journal of Biology, 8(8), 747-755.

https://doi.org/10.2478/s11535-013-0179-0

Petitjean, Q., Jean, S., Gandar, A., Côte, J., Laffaille, P., Jacquin, L. (2019). Stress responses in fish: From molecular to evolutionary processes. Science of the Total Environment, 684, 371-380.

https://doi.org/10.1016/j.scitotenv.2019.05.357

Pradhan, S.C., Patra, A.K., Pal, A. (2014). Hematological and plasma chemistry of Indian major carp, Labeo rohita (Hamilton, 1822). Journal of Applied Ichthyology, 30(1), 4854.

https://doi.org/10.1111/jai.12297

Prusty, A.K., Kohli, M.P.S., Sahu, N.P., Pal, A.K., Saharan, N., Mohapatra, S., Gupta S.K. (2011). Effect of short-term exposure of fenvalerate on biochemical and haematological responses in Labeo rohita (Hamilton) fingerlings. Pesticide Biochemistry and Physiology, 100(2), 124129.

https://doi.org/10.1016/j.pestbp.2011.02.010 
Relić, R.R., Hristov, S.V., Vučinić, M.M., Poleksić, V.D., Marković, Z.Z. (2010). Principles of fish welfare assessment in farm rearing conditions. The Journal of Agricultural Science, 55(3), 273-282.

https://doi.org/10.2298/JAS1003273R

Rey-Vázquez, G.R., Guerrero, G.A. (2007). Characterization of blood cells and hematological parameters in Cichlasoma dimerus (Teleostei, Perciformes). Tissue and Cell, 39(3), 151-160.

https://doi.org/10.1016/j.tice.2007.02.004

Rodwell, V.W. (1988). Metabolism of proteins and amino acids. P. 265-319, In: Harper's review of biochemistry (Ed. Martin, D.W., Mayes, P.A., Rodwell, V.W.). Published by Lange Medical Publications, California.

Sarkar, S., Ghosh, P.B., Sil, A.K., Saha, T. (2011). Heavy metal pollution assessment through comparison of different indices in sewage-fed fishery pond sediments at East Kolkata Wetland, India. Environmental Earth Sciences, 63(5), 915924.

https://doi.org/10.1007/s12665-010-0760-7

Simmons, D.B.D., Miller, J., Clarence, S., McCallum, E.S., Balshine, S., Chandramouli, B., Cosgrove, J., Sherry, J.P. (2017). Altered expression of metabolites and proteins in wild and caged fish exposed to wastewater effluents in situ. Scientific Reports, 7, 17000.

https://doi.org/10.1038/s41598-017-12473-6
Sopinka, N.M., Donaldson, M.R., O'Connor, C.M., Suski, C.D., Cooke S.J. (2016). Stress indicators in fish. P.405-462. In: Biology of stress in fish: Vol. 35. Fish physiology, $1^{\text {st }}$ Edition (Ed. Schreck, C.B., Tort, L., Farrell, A.P., Brauner, C.J.), Published by Academic Press, Amsterdam. https://doi.org/10.1016/B978-0-12-802728-8.00011-4

SWRE (2007). Monitoring and modeling of discharge of Dry Weather Flow (DWF) to East Kolkata Wetlands (EKW). Final Report. Kolkata: School of Water Resources Engineering, Jadavpur University, p 62.

Valon, M., Valbona, A., Fahri, G., Qenan, M., Dhurat, K., Fatmir, C. (2013). Evaluating environmental pollution by applying oxidative stress biomarkers as bioindicators of water pollution in fish. Polish Journal of Environmental Studies, 22(5), 1519-1523.

Wahli, T. (2002). Approaches to investigate environmental impacts on fish health. Bulletin of the European Association of Fish Pathologists, 22(2), 126-132.

Wintrobe, M.M. (1975). Clinical hematology. $7^{\text {th }}$ Edition, Philadelphia: Lea and Febiger.

Zikić, R.V., Stajn, A.S., Pavlovic, S.Z., Ognjanovic, B., Maletic, S., Markovic, M., Djokovic, L.D., Radojicic, R.M., Saicic, Z. (2002). Effect of acute hypoxia on the energy status and antioxidant defense system in the blood of carp (Cyprinus carpio L.). Archives of Biological Science Belgrade, 54(1-2), 11-18.

https://doi.org/10.2298/ABS0202011Z 